„Przekłady Literatur Słowiańskich”. T. 9, cz. 3

ISSN 2353-9763 (wersja elektroniczna)

DOI 10.31261/PLS.2019.09.03.12

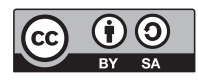

\title{
Bibliografia przekładów literatury polskiej w Macedonii w 2017 roku
}

\section{The Bibliography of Translations of Polish Literature in Macedonia in 2017}

\author{
Lidija Tanuševska
}

iD https://orcid.org/0000-0001-5465-960X

SS. CYRIL AND METHODIUS UNIVERSITY IN SKOPJE

lidkapol@yahoo.com

Data zgłoszenia: 16.10 .2018 r. ～～Data akceptacji: 18.12.2018 r. 


\section{Publikacje książkowe}

1. Dąbrowska Krystyna: Wiersze / Stihovi.

Prev. Zvonko D i m o s k i. Struga, Struški večeri na poezijata, 2017, 60 s. [poezja].

2. Dąbrowska Krystyna: Wiersze / Stihovi.

Prev. Zvonko D i m o sk i. W: Koj e koj. Poezija od pet kontinenti.

Red. Slave Gjorgjo D i m o s k i. Struga, Struški večeri na poezijata, 2017, s. 262-273 [poezja].

3. Jędrzejewska-Wróbel Roksana: Humory Hipolita Kabla / Raspoloženijata na Hipolit Kolbas.

Prev. Filip D i m e v s k i. Skopje, Begemot, 2017, s. 40 [proza].

4. Kapuściński Ryszard: Jeszcze dzień życia / Ušte eden den život. Prev. Lidija Ta n u š e v s k a. Skopje, Begemot, 2017, 135 s. [proza].

5. Karpowicz Ignacy: Sońka / Sonja.

Prev. Filip D i m e v s k i. Skopje, Begemot, 2017, 163 s. [proza].

6. Krynicki Ryszard: Wiersze / Stihovi.

Prev. Zvonko D i m o sk i. W: Koj e koj. Poezija od pet kontinenti.

Red. Slave Gjorgjo Dimoski. Struga, Struški večeri na poezijata, 2017,

s. 274-281 [poezja].

7. Maleszka Andrzej: Magiczne drzewo. Czerwone krzesło / Magično drvo.

Crvenoto stolče.

Prev. Zvonko D i m o ski. Skopje, Libi, 2017, 288 s. [proza].

8. Mrożek Sławomir: Słoń / Slon.

Prev. Filip D i m e v s k i. Skopje, Begemot, 2017, 206 s. [proza].

9. Parys Magdalena: Magik / Magioničar.

Prev. Milica M i r k u lov s k a. Skopje, Antolog, 2017, 499 s. [proza].

10. Reymont Władysław: Bunt / Bunt.

Prev. Zvonko D i m o s ki. Bitola, Vostok, 2017, 241 s. [proza].

11. Żeromski Stefan: Ludzie bezdomni / Bezdomnici.

Prev. Ilija Trajk ov ski. Skopje, Martina, 2017, 329 s. [proza].

LIDIJA TANUŠEVSKA | prof. dr hab., pracuje w Katedrze Slawistyki na Wydziale Filologicznym im. Blaże Koneskiego Uniwersytetu Świętych Cyryla i Metodego w Skopje w Macedonii; prowadzi zajęcia z literatury polskiej, praktyki przekładu z języka polskiego na macedoński i przekładoznawstwa. Jej zainteresowania badawcze obejmują głównie zagadnienia przekładoznawstwa, ale również językoznawstwa porównawczego i literaturoznawstwa. Jest wybitnym tłumaczem literatury polskiej na język macedoński. Została wyróżniona nagrodami translatorskimi, m.in. Nagrodą im. Ryszarda Kapuścińskiego za przekład 
Imperium na nowy język (2015). W 2017 roku wydała monografię Przyczynek do gramatyki konfrontatywnej języka macedońskiego i języka polskiego. Przełożyła książki: Bieguni, Prawiek i inne czasy oraz E.E. Olgi Tokarczuk, a także opowiadania i nowele C.K. Norwida, B. Schulza, S. Grabińskiego i in. 